\title{
Vroue en die sosio-kulturele narratief
}

Y Dreyer

(UP)

\section{ABSTRACT}

\section{Women and the sosio-cultural narrative}

The socio-cultural narrative mirrors the dominant system of values in society. This system contains the values of and protects the interests of the dominant group. It is expression of the prevailing ideology of a culture. In Western sociery patriarchy is still the dominant ideology. Feminist hermeneutics aims to illuminate the disparity between the sexes in the socio-cultural narrative as one of more urgent problems in society. This article discusses different aspects of the "coherent philosophy" behind this socio-cultural narrative. Dominant theories in theology, which result from this ideology, are exposed. The article focuses on the role of pastoral interaction with women and points out the consequences for pastoral care.

\section{INLEIDING}

In haar werk, "Rethinking feminism, the animus, and the feminine", sê Polly Young-Eisendrath 1 onder andere: "What feminism has revealed, in its many forms from theology to literary criticism to psychology, is that the silencing and trivializing of women and their ideas affect all of us all the time in the way we expect the world and ourselves to be". In die lig van die aanname dat die samelewing die beste van sigself wil glo², sou 'n mens wil aanvaar dat die posisie van die vrou hier aan die einde van die twintigste eeu reeds reggestel is. Vroue (in die Weste, in elk geval) het nou toegang tot alle geleenthede, kan beskik oor die persoonlike vryheid om hulle eie keuses te maak en besluite te neem. Vroue kan nou beskik oor die ekonomiese mag om selfstandig te lewe en oor die seksuele mag om beheer uit te oefen oor hulle eie liggame en die moontlikheid tot prokreasie. Daar word nie meer openlik in kerklike of samelewingstrukture teen vroue gediskrimineer nie. Trouens, diskriminasie is in die meeste Westerse lande teen die wet. Vroue word nie meer uitgesluit nie. Hulle word dus as gelykwaardige vennote aanvaar.

Maar is die realiteit van die huidige situasie van vroue wel so 'n netjies afgeronde geheel wat korreleer met die mooi ideale van die 
samelewing en die post-moderne paradigma? Ook in die werklikheid van die vrou bestaan die situasie uit 'n kompleksiteit van sake. Sommige is positief en ander negatief, sommige korreleer met die ideale van die samelewing en ander verteenwoordig 'n gestolde erfenis uit die geskiedenis wat bots met hedendaagse ideale. In hierdie artikel wil ek fokus op vroueervaring binne die hedendaagse kultuur. Ek vind Joan Laird ${ }^{3}$ se konsep "socio-cultural narrative" besonder bruikbaar om met die hedendaagse kultuur in dialoog te tree.

'n Sosio-kulturele narratief orden die samelewing. Dit weerspieël die waardes van die samelewing en definieer rolle vir die onderskeie persone in hulle onderskeie posisies. In plaas van om mislei te word deur die mooi klinkende gestelde ideale van die samelewing en dit as die werklikheid te aanvaar, kan fyn luister na die sosio-kulturele narratief 'n ander verhaal laat opklink. En hierdie ander verhaal is waarskynlik die meer realistiese konteks waarbinne die vrou se eie verhaal vorm aanneem.

Die sosio-kulturele narratief verteenwoordig die dominante waardesisteem van die samelewing. In wese kom dit op dieselfde neer as die begrip meesternarratief ${ }^{4}$. Die dominante waardesisteem behels die waardes van die dominante groep en dit en beskerm die belange daarvan. Sosio-kulturele narratiewe is uitdrukking van die heersende ideologie in 'n kultuur. Die heersende ideologie in die hedendaagse Westerse kultuur is steeds die patriargaat ${ }^{5}$. Die sigbare werklikheid in hedendaagse Westerse samelewings is dat heteroseksuele blanke mans wat besitters en meestal vaders is, die dominante groep in die samelewing is. In ander kulture val die "blank" weg, maar die dominante groep is daar ook heteroseksuele mans wat besitters en vaders is. Die werklikheid van vroue dwarsoor die wêreld kan soos volg opgesom word: "Women are undervalued and threatened in their roles as wives, mothers, farmers, laborers, managers. Their potential to be decision makers, innovators, and equal participants in society is severely undercut by social systems that are discriminatory and relationships that are abusive" 6 .

Die dispariteit tussen geslagte is een van die dringendste probleme in die samelewing. Feministiese studies het hierdie probleem as uitdaging aanvaar en reeds belangrike vordering gemaak om die gemeenskap sterker bewus te mak van die pyn wat dit in die samelewing veroorsaak. Hierdie studies, net soos in die geval van feministiese hermeneutiek, vorm nie 'n eenduidige beweging nie. Algemene kenmerke kan egter wel aangewys word. Marilyn French ${ }^{7}$ bespreek aspekte van hierdie "koherente filosofie":

* die menswaardigheid ("humanity”) van vroue; 
* die pariteit tussen geslagte;

* die noodsaak dat pariteit openbare erkenning moet geniet;

* die pariteit ("equality") tussen aspekte van menslike bestaan wat tradisioneel met vroue geassioseer is en aspekte wat tradisioneel met mans geassosieer is;

* die noodsaak dat ook hierdie pariteit openbare erkenning moet geniet;

* die onlosmaaklikheid tussen waardes wat polities [en ek kan byvoeg: godsdienstig] van aard is en die waardes wat 'n mens se persoon raak;

* die onaanvaarbaarheid van die gaping tussen waardes wat [in beleidsprogramme] aangekondig word en die waardes wat in die daad uitgeleef word.

\section{DIE SOSIO-KULTURELE NARRATIEF}

Omdat die sosio-kulturele narratief die verhaal van die dominante groep in die samelewing is, word dit algemeen as "waar" aanvaar. Daar is geen regverdiging of verdediging daarvoor nodig nie. Die waarheid van hierdie verhaal is vanselfsprekend, logies, natuurlik en deur God gewil. Die sosiokulturele narratief funksioneer onder die oppervlakte, maar word sigbaar wanneer die optrede van sekere mense binne die samelewing die voorgeskrewe rolle bevraagteken. Die wyse waarop die heersende waardes en maniere van doen verdedig word, is met woorde soos "almal weet tog ..." of "dit is tog vanselfsprekend dat..." of 'n appèl dat dit "normaal" is.

Die definisies van wat as "normaal" beskou behoort te word, word egter gewoonlik bepaal binne die patriargale sisteem. Dit is dus vanselfsprekend dat die dominante groep gaan verorden dat hulleself, en hoe hulle dinge sien en doen, "normaal" is. Ander visies, ervarings of norme sal dus ongeldig wees en nie as "normaal" beskou word nie. Schüssler Fiorenza stel dit so: “(B)y making marginalization and stereotypes appear as "natural" or "common sense", they interpret, construct, and legitimize reality from the perspective of elite western men and in the interest of relations of exclusion and domination."

Die sosio-kulturele narratief word onder andere weergegee in televisieprogramme, populêre verhale en advertensies. Dit word instrumente van mag in die hande van die dominante groep in die samelewing waarmee die sosiale identiteit van mense gevorm en gedefinieer word'. Die mees belangrike ideologiese instrumente in 'n samelewing is: die gesin, die onderwysstelsel, godsdiens en die 
massamedia. Met behulp van hierdie middele word mense gesosialiseer in hulle rolle wat die samelewing van hulle verwag om te vervul ${ }^{10}$. In 'n sogenaamde Christelike omgewing word geykte sosiale rolle dikwels goedgepraat as Bybelse eise. Vroue-ervaring word onderdanig gemaak aan die beeld van die sogenaamde deugsame vroue waarvan daar in die Bybel gelees word"11.

Wie krities kyk na die samelewing, sal waarskynlik bewus word van 'n verskil in die mag van mans en vroue. Riet Bons-Storm ${ }^{12}$ definieer mag as "the ability to influence the emotions, thoughts, attitudes, and behavior of others". Mag funksioneer binne menslike relasies. Mag is nie noodwendig skadelik of onderdrukkend nie. Dit kan neutraal beleef word en op 'n positiewe manier gebruik word. Om hierdie ambivalensie uit te druk word soms 'n onderskeid tussen "mag" (power) en "gesag" (authority) getref13. Laasgenoemde sou dan "mag" in die positiewe sin van die woord wees en eersgenoemde in die negatiewe sin van die woord. Die verskil tussen "power" en "authority" sou hiervolgens verband hou met die sosiale posisie van waaruit iemand hy of haar mag kan uitoefen ten spyte van weerstand daarteen. Die "opdragte" van iemand in 'n gesagsposisie word egter nie noodwendig teengestaan nie, omdat so 'n persoon 'n "legitimate relation of domination and subjection" sou verteenwoordig.

Ralf Dahrendorf ${ }^{14}$ se standpunt dat dit nie die feit van hiërargie as sodanig is wat aanleiding tot konflik gee nie, maar die "oneweredige verspreiding van gesag" $k$ an wel 'n waarheidselement bevat. Dit bied egter nog nie 'n antwoord op die probleem van die skade wat magsmisbruik tot gevolg het nie. Die uitskakeling van, byvoorbeeld, vroue se oneweredige toegang, in vergelyking met mans, tot gesagsposisies lei nie op sigself tot die uitskakeling van magsmisbruik nie. Die oplossing lê myns insiens in 'n visie op die bewusmaking dat hiërargie die inherente verleiding bevat om mag te misbruik. Om vroue en mans bewus te maak van magsmisbruik verteenwoordig 'n visie op "feminisme" wat te onderskei is van maar net nog 'n ander partisanebeweging wat maghebbers beveg15. Marilyn French ${ }^{16}$ sê tereg dat kampvegters van die waarde van vroue-ervaring "do not want women to assimilate to society as it presently exists but to change it". In haar verstaan van die "revolusionêre" en "transformerende" bedoeling van feministiese studies wil sy die begrip "mag" met iets anders as die "central idea of human society" vervang17. Dit kom neer op 'n bewusmaking dat die uitoefening van mag in 'n negatiewe sin die beperking en onderdrukking van ander tot gevolg het. Sulke negatiewe mag beperk die ruimte waarbinne 'n ander persoon keuses kan uitoefen. Dit ontneem die ander die mag om die subjek van sy of haar eie besluite te kan 
wees. Geweld is 'n onderdrukkende mag wat fisies, psigologies of geestelike verwoesting veroorsaak.

In haar boek, Powers of the weak, maak Elizabeth Janeway ${ }^{18}$ die volgende betekenisvolle opmerking: "What women want is a world that offers more than two choices - male role, female role, and nothing else". Sy wys tereg daarop dat die "feminist project" nie maar bloot gaan om die verbreding van keuses wat vroue in die samelewing kan uitoefen nie, maar "to change a worldview": "The ability to add new perceptions, purposes, and goals to the dynamics of social interaction is not something that the powerful expect from any of the weak: but the powerful are wrong"19. Hoe meer van die volgende faktore aan iemand toegeskryf kan word, hoe groter die persoon se mag: manlik, heteroseksueel, besittings, goed opgelei, jonk, nie liggaamlik of geestelik gestrem nie ${ }^{20}$. So 'n lys van bemagtigende faktore gaan terug na Aristoteles wat gemeen het dat mag en orde in 'n samelewing natuurlikerwys by die manlike geslag hoort. Vroulike persone was volgens hom in wese gebreklik. In De Generatio Animalium (II, 3:737a)21 noem hy vroue "gebreklike mans", "emosioneel", "passief" en "gevangenes in hulle eie liggaamsfunksies". Aristoteles het Westerse denke op ' $n$ ingrypende wyse beïnvloed.

Die verskil tussen die mag van mans en dié van vroue in die Westerse kultuur en samelewing is nie maar net 'n neutrale of onskuldige saak nie 22 . Die lyding wat vanweë hierdie magswanbalans veroorsaak word, kan nie ligtelik opgeneem word nie. Die magswanbalans in die patriargale sisteem laat baie vroue onder verbale en fisieke geweld ly. Laasgenoemde gaan dikwels met seksuele geweld gepaard. Selfs om vroue stil te maak, is 'n vorm van geweld wat gepleeg word deur groepe met mag teenoor dié wat maghebbers beskou as mag(te)loos. Hiërargieë kan mense dwing tot stilte. Volgens die patriargale waardesisteem is 'n man se eintlike plek in die openbare sfeer waar die belangrike besluite geneem word. Vroue se vermeende plek is die private sfeer waar daar omgesien word na liggaamlike behoeftes en na kinders.

Deesdae word vroue wel toegelaat om tot op 'n sekere vlak in die openbare sfeer te funksioneer. Dit gebeur egter steeds op die voorwaardes wat mans stel. Buiten hulle rol in die openbare lewe moet vroue meestal volle verantwoordelikheid dra vir die private sfeer. Hulle gaan dus gebuk onder ' $n$ dubbele werklas ${ }^{23}$. In die patriargale sosio-kulturele narratief is daar met ander woorde slegs 'n beperkte hoeveelheid sosiaal-aanvaarbare rolle vir vroue beskikbaar. In al hierdie rolle is ' $n$ man teenwoordig. Volgens Bons-Storm ${ }^{24}$ gaan dit hoofsaaklik daarom dat ' $n$ vrou volgens hierdie sisteem, 'n man in die sentrum van haar lewe moet hê. 
Volgens die post-moderne denker, Michel Foucault25, het die moderne paradigma die Middeleeue se "stede vir melaatses", die wrede kasteel van orde ${ }^{26}$, vervang met die onsigbare kerkers van die moderne bewussyn en gewete. Vandag het geslagtelike ongelykheid en die man se heerskappy oor die vrou, wat in die geskiedenis nog altyd die reël was, onaanvaarbaar geword ${ }^{27}$. In die modernistiese pardigma is andersheid as 'n afwyking van die reël ('n anomalie) ervaar en dus as problematies. Die probleem is opgelos deur wat anders is binne die dominante reëlmatigheid, in te forseer of uit te ban asof dit nie bestaan nie.

Baie vroue speel dan gewoon die rolle wat aan hulle voorgeskryf word. Sosialisering in die dominante sosio-kulturele narratief beteken dat vroue skuldig en skaam sal voel wanneer hulle nie die rolle speel wat aan hulle toegeken is nie. Hierdie gevoelens bekruip hulle selfs wanneer hulle wel die rolle speel, maar dit nie goed genoeg doen volgens die heersende patriargale standaarde nie. Weer eens is etikette byderhand (vir vroue maar nie vir mans wat dieselfde dinge doen nie), naamlik "slegte vrou", "slegte ma", "verleidster", "selfsugtig", en vele meer ${ }^{28}$. Gevoelens van skuld en skaamte is dikwels so diep gesetel in vroue se persoonlikhede dat dit selfs professionele, "geëmansipeerde" vroue bly teister - "There is hardly a professional woman who does not feel guilt in her relationships with her partner or children" 29 .

\section{DIE TEOLOGIEË VAN DIE SOSIO-KULTURELE NARRATIEF}

Vroue woon in 'n samelewing en aanbid in kerke waar mans eeue lank die leiersposisies beklee. Dit was dus nog altyd mans wat die mag gehad het om in kerk en teologie te besluit hoe dinge gedoen word, wat gesê word, hoe dit gesê word en wie dit mag sê. Die sosio-kulturele narratief beïnvloed ook hoe die rol van vroue gelegitimeer word in akademiese en teologiese teorieë. Heersende teologiese teorieë ${ }^{30}$ dien die belange van die dominante groep.

In haar navorsing oor die probleme wat vroue in Duitsland met die kerk het, kom Andrea Schulenburg ${ }^{31}$ die volgende teë. Vroue ervaar dat hulle benadeel word op grond van hulle geslag (seksisme), dat hulle die bevoorregting en eensydige heerskappy van mans (patriargalisme) onaanvaarbaar vind, dat die man ook in die kerk beskou word as die norm vir menswees (androsentrisme), dat die vrou gereduseer word tot vermeende "natuurlik-vroulike" eienskappe (sag, emosioneel, selfopofferend, dienend, versorgend). Hierdie eienskappe wat aan vroue toegeken word, bepaal vroue se waarde en die doelwitte vir hulle lewens. Vroue word op grond 
hiervan in die kerklike en samelewingstrukture gekondisioneer tot sekere gedragspatrone en rolle (swygsaam, op die agtergrond, verhoudingsgerig).

In die dominante patriargale teologieë word God meesal uitgebeeld as manlik, vader en almagtig. Die gevolg daarvan is dat mans se selfbewussyn bevestig word as redelike wesens met mag. Hulle geslag kan as 't ware saamgedink word met die goddelike. $\mathrm{Na}$ sowel God as die man word verwys as "hy" en "hom". Die vrou is anders as man en God. Waar God en man "hy" is, is die vrou "sy". Na God en die man word verwys as "hom", maar na die vrou as "haar". Wanneer daar godsdiensfenomenologies in vroulike terme na die goddelike verwys word, word dit in verband gebring met fertiliteit. Dan argumenteer die tradisionele Christelike teologie dadelik dat God beslis nie 'n god van fertiliteit is nie. God is ' $n$ God van die Woord. Bons-Storm ${ }^{32}$ vra die kritiese vraag of "vrou" dan gereduseer kan word tot borste en 'n baarmoeder? Is so 'n reduksie van die vrou se wese en waarde die rede waarom 'n godheid na wie daar in vroulike terme verwys word, noodwendig 'n vrugbaarheidsgodin moet wees? Hoekom kan "God", in vroulike beeld geartikuleer, nie ook 'n God van die Woord wees nie?

Vanuit die perspektief van konteks, is dit duidelik dat die teologiese tradisie en Skrifgebruik in 'n patriargale, androsentriese konteks ontstaan het. Op ' $n$ androsentriese wyse is die man nie geslagspesifiek gesien as man, met ander woorde 'n deel (boonop nog 'n minderheid) van die mensheid nie. Mans is gewoon gesien as "mens" wat algemeen menslike uitsprake kan maak en menslike ervaring kan verwoord. Wanneer vroue aan die woord is, is hulle egter nooit die verteenwoordigers van die mensheid nie. Hulle word altyd geslagspesifiek gesien. Wanneer hulle praat, verwoord hulle alleenlik die vroueperspektief. Hoewel daar in die hedendaagse samelewing, akademiese wêreld en in die teologie 'n veel groter bewussyn van die saak is, verraai ons taalgebruik steeds die stand van sake. Die generiese terme "teologie", "hermeneutiek", "dokter", "predikant" verwys na of die arbeid van of die persone van mans. As hierdie persone vroue is of die sake deur vroue bedryf word, word die generiese term nie meer gebruik nie. 'n Geslagspesifieke term word dan gebruik: "feministiese teologie", "feministiese hermeneutiek", "vrouedokter" en "vrouepredikant". Met ander woorde, wat anders is as die (manlike) norm, word gespesifiseer. 
Die meeste pastors (mans en vroue) sal sekerlik nie vir 'n oomblik aanvaar dat hulle moontlik seksisties is of optree nie. Hulle meen waarskynlik eerlik en opreg dat hulle op 'n oop manier na mense luister, aan alle mense die ruimte bied om hulle verhale ongehinderd te vertel en vanuit hulle opleiding en met hulle ontwikkelde vaardighede aan alle mense die beste moontlike pastorale hulp verleen.

Seksisme is egter diep ingewortel in ons samelewing en word gegrond in die diepste vrese van mans en vroue. Seksisme is irrasioneel, dus is mense grootliks onbewus daarvan. Ook vir sommige vroue wat die slagoffers daarvan is, bly dit 'n leeftyd lank irrasioneel en onbewus. Ander vroue word bewus daarvan dat iets êrens verkeerd is wanneer hulle seerkry, verneder, geïgnoreer, stilgemaak of op die een of ander wyse onmenswaardig behandel word. So word die irrasionele na die bewussyn en na die oppervlakte gebring. Geleidelik word die algemene verskynsel van seksisme in die kerk en samelewing vir dié vroue op 'n pynlike manier sigbaar.

Die pastor se selfvertroue dat die vrou in die pastorale interaksie haar regmatige plek inneem, is waarskynlik gegrond in die sekerheid dat hy of sy as pastor die mens ken, die mens se gevoelens verstaan en simpatiek kan benader in die pastorale interaksie. Oor die pastor sê BonsStorm ${ }^{33:}$ "It is plausible to assume that the average pastor and pastoral counselor is socialized in the dominant patriarchal culture. In many men (including male counselors and pastors), this socialization brings about ambivalence toward women. Under the layer of openness to emancipation one often finds an ever ready amount of hate and (verbal or physical) violence toward women in general. A relatively thin veneer of emancipation theory and practice often covers a deep-seated longing for women to play their proper roles: the selfsacrificing mother, the attractive wife standing behind her man, or the dutiful daughter".

Die pastor se vooronderstellings oor wat wesenlik "manlik" of "vroulik" is, sowel as die pastor se begrip (of gebrek daaraan) van die wêreld van die spesifieke geslag, bepaal haar of sy persepsies, argumente en gevolgtrekkings in die pastorale interaksie. Die pastor kan vanuit hierdie vooronderstellings vroue en mans stereotipeer. Die patriargale sosio-kulturele narratief se vooronderstellings oor "man" en "vrou" kan herken word in die kenteorie van die moderne era. Op die vraag wie toegang het tot "ware". kennis, antwoord hierdie epistemologie met 'n dichotomie tussen rede/manlik/patriargale/orde/rasionaliteit/geloofwaardigheid 
teenoor liggaamlik/vroulik/chaos/irrasioneel/ongeloofwaardig. Manwees word geassosieer met orde en rede, terwyl vrouwees geassosieer word met chaos en onredelikheid. Die gevolge hiervan vir die pastoraat met vroue is ingrypend ${ }^{34}$. As vroue vryelik met kennis en idees kan omgaan vanuit hulle eie perspektief, sou dit die rasionaliteit van die sisteem bedreig. Volgens hierdie sisteem sou dit ondenkbaar wees dat vroue op dié wyse met kennis kan omgaan. Kennis (redelik, logies) is vanweë die aard daarvan deel van die eksklusief manlike domein. Om ruimte te gee aan vroue om ook as subjekte met kennis om te gaan en dit vanuit 'n eie perspektief te doen, is dus nie net ' $n$ kwessie van 'n bietjie opskuif om plek te mak vir 'n ander nie. Dit beteken dat die basis van 'n denkstruktuur in die gedrang kom. Vroue beweeg uit hulle aangewese domein (onlogies, irrasioneel, chaos) en bedreig mans se superioriteit en posisie.

Volgens die patriargale waardesisteem is 'n man se eintlike plek in die openbare sfeer waar die belangrike besluite geneem word. Vroue as substruktuur se eintlike plek is die private sfeer waar daar omgesien word na liggaamlike behoeftes en na kinders. Deesdae het vroue nie net toegang tot kennis nie, maar word ook toegelaat om tot op 'n sekere vlak in die openbare sfeer te funksioneer. Dit gebeur egter op die voorwaardes wat die manlike wêreld stel. Die beheer bly in die hande van mans: eggenote wat hulle vroue "toelaat" of om nie te werk nie, of om die motor te bestuur na waar hulle wil of moet wees. So het manlike werkgewers ook beheer oor of hulle vroue wil aanstel/bevorder of nie. Ek het hierbo reeds daarop gewys dat, ten spyte van opleiding en 'n uitbeweeg in die openbare sfeer wat vir vroue, gegewe hulle geskiedenis, as besliste "vooruitgang" aangeteken moet word, hulle egter steeds volle verantwoordelikheid dra vir die private sfeer. Dus gaan hulle gebuk onder 'n dubbele werklas. In 'n publikasie van die Verenigde Volke getitel Women: Challenge to the year 200035 word die volgende statistiek gevind: Vroue maak die helfte van die wêreld se bevolking uit, doen twee-derdes van die werk, maar ontvang slegs een tiende van die wêreld se inkomste en besit een honderdste van die wêreld se eiendom.

Die dominante narratief is duidelik herkenbaar in die teorieë waarmee die pastor werk, sowel teologiese teorieë, soos reeds uitgewys, as psigologiese teorieë. Die psigologiese teorieë bevat vooronderstellings rakende wat as "normaal" of "vanselfsprekend" gesien word ten opsigte van vroue, mans, moeders, vaders, menslike verhouding en menslike ontwikkeling. Ook hierdie vooronderstellings is meestal verskuil en funksioneer onbewustelik. Hulle stuur die pastor in sy of haar persepsie en interpretasie van die woorde en optrede van die pastorant. Psigologiese 
teorieë vorm die pastor se manier van kyk en luister ${ }^{36}$. Indien die teorieë onderliggend aan die pastor se pastorale werk inpas by die sosio-kulturele narratief en dien om dit in stand te hou en voort te sit, bestaan die gevaar dat die pastor, sonder om eens daarvan bewus te wees, vroue sal terugdruk in die beperkings van die aanvaarde rolle. Die dominante patriargale sosiokulturele narratief oor vroue beklemtoon die rol wat hulle in relasie tot mans speel. Daarom word die hooftemas in die dominante narratief oor vroue (ook in die psigologiese teorieë en hulle vooronderstellings wat ten grondslag van die pastoraat lê) dié van seksualiteit en moederskap.

In 'n baanbrekerwerk op hierdie terrein het Miriam Greenspan ${ }^{37}$ aangetoon hoe die mediese model in terapie en berading funksioneer. Die model gaan van die standpunt uit dat die terapeut die kundige is wat oor die kennis en oor die waarheid rakende die "pasiënt" beskik. Dit is 'n model wat in die moderne paradigma ontwerp is en dit staan dus kommunikasie binne 'n subjek-objek interaksie voor. Die terapeut gaan van die veronderstelling uit dat die fout by die vrou net op een plek lê, naamlik in haar kop. Die vrou oorstyg met ander woorde nie die rol van slagoffer nie ${ }^{38}$. Terapie veroorsaak vir beide "terapeut" en "kliënt" 'n toestand van "interpersonal pressure cooker" ${ }^{39}$. Die gevaar van magsmisbruik van die kant van die terapeut is ook nie uitgesluit nie ${ }^{40}$. Die terapie is daarop gerig om die vrou se "verkeerde" siening en hantering van haar probleem reg te stel. Dit hou glad nie rekening met die uitwerking wat die strukture waarbinne sy leef, moontlik op haar kan hê nie.

Die doel van 'n narratiewe benadering in die pastoraat ${ }^{41}$ is om mense te help om die probleem te eksternaliseer, om hulle te help om in te sien dat húlle nie die probleem is nie, maar dat "the problem is the problem" 42 "From this perspective, it is proposed that persons' lives are shaped by the meaning that they ascribe to their experience... and by the language practices and cultural practices of self that these lives are recruited into" 43 . Wanneer die pastor se perspektief dié van die kundige is en die pastor gemaklik en salig onbewus ingebed is in die dominante sosio-kulturele narratief, kan 'n stem wat dreig om 'n "onvanpaste" verhaal te vertel, as steurend, bedreigend en ongemaklik beleef word. Die pastor het dan 'n keuse: of hy of sy probeer om die lastige stem stil te maak met die kundige se verklaring van hoekom die probleem by die vrou self lê; of die pastor loop die ongemaklike pad van selfbewuswording en selfbewusmaking. Die pastor bly nie onaangeraak nie, maar word aangespreek deur die vrou se eie outentieke verhaal. Die pastor is in dialoog besig om te soek na sy of haar eie waarheid, terwyl daar saam gesoek word na die vrou se waarheid.

Die kliniese psigologie en die pastoraat is ontwikkel binne ' $n$ patriargale verwysingsraamwerk. In beide die pastoraat en die patriargaat 
is die saak van geslag en die implikasies daarvan grootliks geïgnoreer. Hierdie leemte is langsamerhand gelukkig nou erken en literatuur oor die onderwerp het begin verskyn ${ }^{44}$. Maar as daar werklik in die pastoraat erns gemaak word met geslagtelikheid, sal daar geanaliseer moet word wat dit beteken om in 'n manlike of vroueliggaam te leef. Daar sal ook gekyk moet word na wat dit beteken vir 'n persoon om gelowig te lewe as 'n seksuele en beliggaamde wese. In die dominante narratief waar "hoër" geestelikheid verhef word bo "lae" liggaamlikheid (met die vroueliggaam as die laagste vorm van liggaamlikheid), is sulke analises ondenkbaar. Sulke stemme is al 'n ruk lank besig om op te klink, nie net vanuit die feministiese perspektief nie ${ }^{45}$, maar ook vanuit die manlike perspektief ${ }^{46}$. Ook vanuit die geledere van die gelowiges wat leef in 'n post-moderne wêreld word gepleit vir nuwe denke ten opsigte van liggaamlikheid en seksualiteit in die kerk $^{47}$. Die vraag is of die dominante narratief selfbeskermend optree en die stemme ignoreer of met geweld stilmaak, en of daar geluister word, ten spyte van ongemak, met die oog op aanpassing en vernuwing.

\section{VROUE SE VERHAAL EN DIE SOSIO-KULTURELE NARRATIEF}

In Bons-Storm ${ }^{48}$ se navorsing met vroue in die konteks van die pastoraat, het aan die lig gekom dat heelwat vroue voel hulle kan nie hulle verhaal aan hulle pastor vertel nie. Wanneer vroue met 'n pastor praat, vertel hulle episodes uit die verhaal van hulle lewe. Wat gebeur in ' $n$ verhaal, is dat mense probeer om verbande te vind tussen gebeurtenisse. Verhale is mikro-narratiewe in die struktuur van 'n groter narratief49. 'n Storie is die verbale konstruksie van 'n spesifieke ervaring. Om 'n mens se diepste gevoelens waarvoor die persoon nie eens altyd woorde kan vind nie, aan 'n ander te gee, is 'n blootstellende en soms selfs skrikwekkende ervaring. Daarom is dit absoluut noodsaaklik dat die pastor met die grootste respek sal luister, wat uitgespreek word, sal erken en bevestig en ruimte daarvoor hê dat die vrou dit self vanuit haar outentieke ervaring vertel het. Waar die respek, aanvaarding en ruimte nie teenwoordig is nie, word ' $n$ vrou se "siel" laat val. Wat vroue in 'n pastor soek is "... a theological presence, a listening, supportive, nonthreatened and compassionate presence... A woman desires that her identity be reshaped by a theology of grace, that her experience be affected by a theology of hope, and that intimacy needs be addressed within the family of faith"50.

Die sosio-kulturele narratief behels die feit dat vroue in hierdie eeu in die werksfeer begin inbeweeg het, en deel uitmak van die dominante narratiefs! 
Joan Laird52 gebruik die konsep "unstory" vir die verhaal wat nooit vertel word nie. Die vrou ervaar sulke verhale as te pynlik en skandelik. Om die pynlike verhaal te vertel, sou beteken om dit weer te moet ervaar nie net die gebeurtenis self nie, maar ook die gevoelens van pyn en skaamte wat daarmee gepaard gegaan het. Sulke verhale kan alleenlik vertel word as daar absolute sekerheid is dat die een wat luister, werklik sal verstaan, sal erkenning gee aan die verskriklike gevoelens en ten spyte van alles die persoon wat vertel, sal aanvaar. As die pyn en skaamte te diep lê en die eie verhaal te verwarrend is (en daarmee saam die soeke na 'n outentieke identiteit), word die ervaring só diep weggebêre dat dit vir alle praktiese doeleindes vergeet word.

Ervarings van vroue word onder andere 'n "unstory", wanneer die dominante waardesisteem die verhaal nie kan akkommodeer nie. So 'n verhaal bevat dikwels rolle vir vroue wat bots met die "behoorlike" rolle. As vroue "onvanpaste" ervarings beleef het, is geen "goeie" storie vir hulle moontlik nie. Alleen wanneer mense mekaar kan aanvaar as waardevolle persone in eie reg, kan 'n nuwe sosio-kulturele narratief ontstaan met ruimte vir "unstoried" ervarings en kan nuwe rolle vir vroue gebore word53.

\section{NOTAS:}

1 P Young-Eisendrath, "Rethinking feminism, the animus, and the feminine" in: C Zweig (ed), To be woman: The birth of the conscious feminine, Los Angeles $1990,160$.

2 Die kritiese teorie, waar onder andere Habermas (vgl J J Snyman, “Die wetenskapsopvatting van die Frankfurtse Skool” in: J J Snyman \& P G W du Plessis (reds), Wetenskapsbeelde in die geesteswetenskappe, Pretoria 1987, 155 177) se kommunikatiewe handelingsteorie val, wil 'n verandering van ervaring teweegbring sodat daardie ervaring wat voortspruit uit versluierde probleme in die samelewing, aan die lig kan kom. Die kritiese teorie is daarom geïnteresseerd in 'n rasionaliteit wat fokus op hoe die samelewing sigself organiseer ten opsigte van die nood wat in die samelewing ervaar word. Die teorie wys uit dat die spanning in die samelewing nie klop met die samelewing se idee van die ideaal nie. Die kritiese teorie verteenwoordig 'n kritiese denke wat begrip toon vir die mens. Hierdie begrip is in stryd met die ideaal wat die samelewing meen tog in die samelewing aanwesig is. Omdat die samelewing van sigself die goeie verwag, bestaan daar nie altyd 'n bewuste insig in die dinge wat hierdie ideaal verwring nie. Die kritiese teorie bevorder bewuswording.

3 J Laird, "Women and stories: Restorying women's self-constructions" in: $M$ McGoldrick, C M Anderson \& F Walsh (Eds), Women and families: A framework for family therapy, New York 1989, 430. 
Die begrip "meestemarratief" wat hier gebruik word, word ontleen aan die werk van J-F Lyotard wat onderskei tussen métarécits (meester- of metanarratiewe) en petits récits (klein narratiewe of kleingeskiedenisse). Kyk B Readings, Introducing Lyotard, London 1991, 63; A P B Breytenbach, "Meestemarratiewe, kontranarratiewe en kanonisering - 'n Perspektief op sommige profetiese geskrifte", Herwormde Teologiese Studies 53/4 (1997), 1163-1167.

$5 \quad$ Kyk R Bons-Storm, The incredible woman: Listening to women's silences in pastoral care and counseling, Nashville 1996, 50. Vergelyk ook E Dodson Gray, Patriarchy as a conceptual trap, Wellesley (MA), 1982.

6 M J Gillis, "A call for the feminization of human rights", Church \& Saciety 88/4 (1998), 80.

7 M French, Beyond power: On uomen, men, and morals, New York 1985, 442444.

8 E Schüssler Fiorenza, "Introduction: Feminist liberation theology as critical Sophialogy" in: E Schüssler Fiorenza (Ed), The power of naming: A Concilium reader in feminist liberation theology, New York 1996, xvii.

9 Bons-Storm, $a w, 1996,50-51$.

10 Vergelyk M J Mananzan, "Education to femininity or education to feminism?" in: E Schüssler Fiorenza (Ed), The power of naming: A Concilium reader in feminist liberations theology, New York 1996, 187.

11 Vergelyk J Schaberg, "[The] A feminist [contribution] experience of historical Jesus scholarship" in: J G Lawler (Ed), The 1994 Annual of Hermeneutics \& Social Concern, New York 1994, 280, stel dit so: “(B)iblical and traditional images of women go hand in hand with the denial of womens' rights to control their own bodies and their lives."

12 Bons-Storm, $a w, 1996,25$.

13 Vergelyk R Dahrendorf, Class and class conflict in industrial society, Stanford, CA 1959, 165, 172-173; R Dahrendorf, "Out of Utopia: Toward a reorientation of sociological analysis" in: Essays in the theory of society, Stanford 1968, 107128.

14 R Dahrendorf, "On the origin of inequality among men" in: Essays in the theory of society, Stanford 1968, 176.

15 Vergelyk R K Rigsby, “Jungians, archetypalists, and fear of feminism" in: J G Lawler (Ed), The 1994 Annual of Hermeneutics \& Social Concern, New York 1994, 37.

16 French, $a w, 1985,444$.

17 Rigsby, a w, 1994, 37. Vergelyk ook R Eisler, Sacred Pleasure: Sex, myth \& the politics of the body - new paths to power and love, New York 1995.

18 E Janeway, Powers of the weak, New York 1980, 13.

19 Janeway, $a w, 1980,14$.

20 Bons-Storm, $a w, 1996,25-26$.

21 D Wilshire, "The uses of myth, image and the female body in revisioning knowledge" in: A M Jaggar \& S R Bordo (Eds), Gender/body/knowledge: Feminist reconstruction of being and knowing, New York 1992, 93.

22 Vergelyk Bons-Storm, $a w, 1996,25$.

23 Vergelyk Bons-Storm, $a w, 1996,50$. 
Bons-Storm, $a w, 1996,54-55$.

$25 \mathrm{M}$ Foucault, Madness and civilization: A history of insanity in the age of reason, New York 1965, 11.

26 C J Beukes, "Michel Foucault en die historisering van Anderswees", Hervormde Teologiese Studies 52/2\&3 (1996), 246.

27 Y Dreyer, “Bybelse huweliksrolle en die moderne egalitêre huwelik (Efes 5:2132)" , Praktiese Teologie in Suid-Afrika, 11/2 (1996), 95. Vergelyk ook V Goldner, "Generation and gender: Normative and covert hierarchies" in: $M$ McGoldrick et al (Eds), a w, 1989, 49.

28 P Boss \& B Thome, "Family sociology and family therapy: A feminist linkage" in: M McGoldrick et al (Eds), a w, 1989, 84-85.

29 Bons-Storm, $a w, 1996,55$.

30 Kyk E Schüssler Fiorenza, "For the sake of our salvation ... Biblical interpretation of the theological task" in: D Durken (Ed), Sin, salvation and the spirit, Collegeville (MN), 1979, 23. Vergelyk P Perkins, "Canon, paradigms and progress?", Biblical Interpretation 1/1 (1993), 91; Bons-Storm, $a w$, $1996,16,52$.

31 A Schulenburg, Feministische spiritualitat: Exodus in eine befreiende Kirche?, Stuttgart 1993, 28-29.

32 Bons-Storm, a w, 1996, 22.

33 Bons-Storm, $a w, 1996,35$.

34 Bons-Storm, $a w, 1996,74$.

35 Verenigde Volke, Women: Challenges to the year 2000, New York (United Nations Department of Public Information) 1991, 10. Vergelyk I Praetorius, "Re-thinking economy: Beyond the androcentric order", Feminist Theology 17, (1998), 89-102; D P Holder \& C M Anderson, "Women, work and the family" in: M McGoldrick et al (Eds), a w, 1989, 357-380.

36 Bons-Storm, $a w, 1996,92-93$.

37 M Greenspan, A new approach to women in therapy, New York 1983.

$38 \quad$ Kyk Rigsby, $a w, 1994,40$.

39 Greenspan, $a w, 1983: 185$.

40 Vergelyk die kritiese bydraes van Adrienne Smith \& Mary Ann Douglas Smith, "Empowerment as an ethical imperative" in: H Lerman \& $N$ Porter (Eds), Feminist ethics in psychotherapy, New York 1990, 43-50; Lerman \& Lerman, "Boundary violations: Misuse of the power of the therapist" in: H Lerman \& $\mathbf{N}$ Porter (Eds), a w, 1990, 51-59; Lerman \& Porter, “The contribution of feminism to ethics in psychotherapy" in: H Lerman \& $N$ Porter (Eds), $a w$, 1990, 5-13.

41 Vergelyk J C Müller, Om tot verhaal te kom: Pastorale gesinsterapie, Pretoria 1996.

$42 \mathrm{~N}$ White $\mathrm{M}$ \& $\mathrm{D}$ Epston, Narrative means to therapeutic ends, New York/London 1990, 39.

43 M White, “Deconstruction and therapy" in: S Gilligan et al (Eds), Therapeutic conversations, New York/London 1993, 35.

44 Vergelyk Greenspan, $a w, 1983$; J Robbins \& R J Siegel, Women changing therapy, New York 1983; J H Robbins, Knowing herself: Women tell their stories in psychotherapy, New York 1990; M Ballou \& N W Gabalac, A 
feminist position on mental health, Springfield, IL 1985; M Glaz \& J S Moessner (Eds), Women in travail and transition: A new pastoral care, Minneapolis 1991.

45 Vergelyk G P Haddon, Body metaphors: Releasing God-feminine in us all, New York 1988; M Daly, Gyn/Ecology: The metaethics of radical feminism, Boston 1979.

46 Vergelyk J B Nelson, Embodiment: An approach to sexuality and Christian theology, Minneapolis 1978; J B Nelson, The intimate connection: Male seruality, masculine spirituality, Philadelphia 1988.

47 Kyk Schulenburg, $a w, 1993,25-26$.

48 Bons-Storm, $a w, 1996,36$.

49 Laird, $a w, 1989,430$.

$50 \quad$ Glaz \& Moessner, $a w, 1991,218,216$.

51 Vergelyk Ballou \& Gabalac, a $w, 1985$, 93-97.

52 Joan Laird, $a w, 1989,437$.

53 Bons-Storm, $a w, 1996,57-59$. 